\title{
MANEJO INTEGRADO DE ÁCAROS EN EL CULTIVO DE ROSAS BAJO INVERNADERO
}

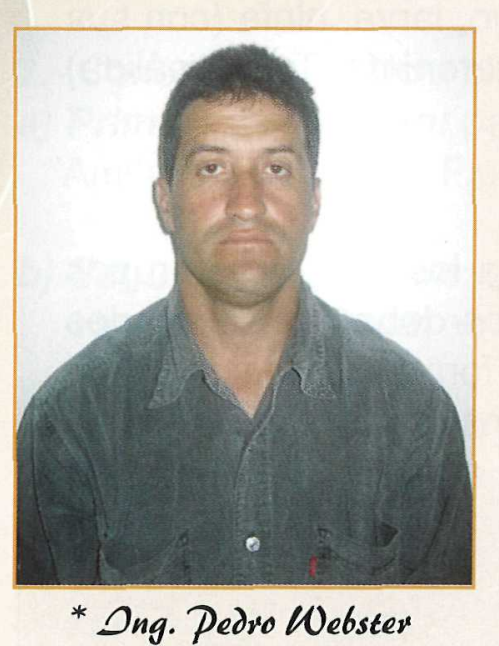

\section{1.- SÍNTESIS}

La floricultura es una actividad económica que brinda grandes réditos al horticultor, su inversión es alta; por lo tanto, requiere, un manejo específico y de mucho cuidado sanitario. Los ácaros reducen cosechas, defolian hojas, diseminan virus y bacterias, dañan el producto a cosecharse.

Su control debe realizarse de una forma integrada como: control de humedad y temperatura, buena nutrición del cultivo, limpieza de malezas, introducción de predadores y control oportuno de focos con productos según su etapa biológica aplicados en rotación tomando en cuenta su acción y principio activo.

\section{2.- DESARROLLO DEL ESTUDIO}

La presente información es el resultado de doce años de trabajo continuo en la explotación intensiva de rosas para la exportación. Según Ferrer y Salvador: "una de las plagas que merece gran cuidado y que causa mucho daño a la rosa es la arañita o ácaros que constituyen un grupo del orden Arácnido, siendo la Familia Tetranychidae, Clase Arácnida; Sub Clase Acari, las llamadas vulgarmente araña común (amarilla, roja) Tetranichus urticae Koch; T. telarius L.; T. althaea v. Hans y los ácaros rojos Panonychus ulmi Koch, de los frutales y P. citri Mc Gregor de los cítricos. En nuestro país, está identificado como T. urticae el ácaro que ataca al rosal".

\section{Ácaro del género Tetranichus urticae, en el rosal}

Este ácaro provoca zonas cloróticas en las hojas de la rosa y se localiza en su inicial fase de ataque en el primer tercio de abajo hacia arriba de la planta, generalmente al envés de la hoja. Si no se controla a tiempo, este se distribuye por toda la planta, ubicándose en el haz y envés de la hoja, en los tallos y botón foliar. En esta etapa forma su telaraña, que sirve de pared protectora contra condicionies que amenacen sus vidas, como son los acaricidas e insecticidas. Posteriormente la planta sufre una defoliación, perjudicando su actividad fotosintética y la calidad de tallo. Es una plaga diseminadora de virus y bacterias.

Como se sabe, la flor que presenta esta plaga no puede ser exportada, por lo tanto es rechazada; mas, si por alguna razón, sea por descuido del personal a cargo de la post cosecha de la flor, esta pasa a encajarse y exportarse el cliente la recibe, y al constatar la presencia de dicha plaga, la rechaza con el debido crédito que deberá asumir la finca productora de donde procede la flor y la posible pérdida del cliente. 


\section{Síntomas provocados por ácaros}

Para realizar un control adecuado de la plaga, se debe conocer claramente su ciclo biológico, pues será más corto cuando la temperatura del medio sea más alta. Dicho ciclo se ubica entre 18 a 24 días y va desde las fases de huevo, larva, ninfa (con sus cinco estados: Ninfocrisálida, Protoninfa, Deutocrisálida, Deuteroninfa, Teliocrisálida) y adulto.

\section{CONTROL}

La arañita tiene una gran capacidad de provocar resistencia a los diferentes grupos químicos, sobre todo cuando se utilizan constantemente. Estos deben ser aplicados con un manejo racional en dosis adecuadas, en rotación de formas de acción y de

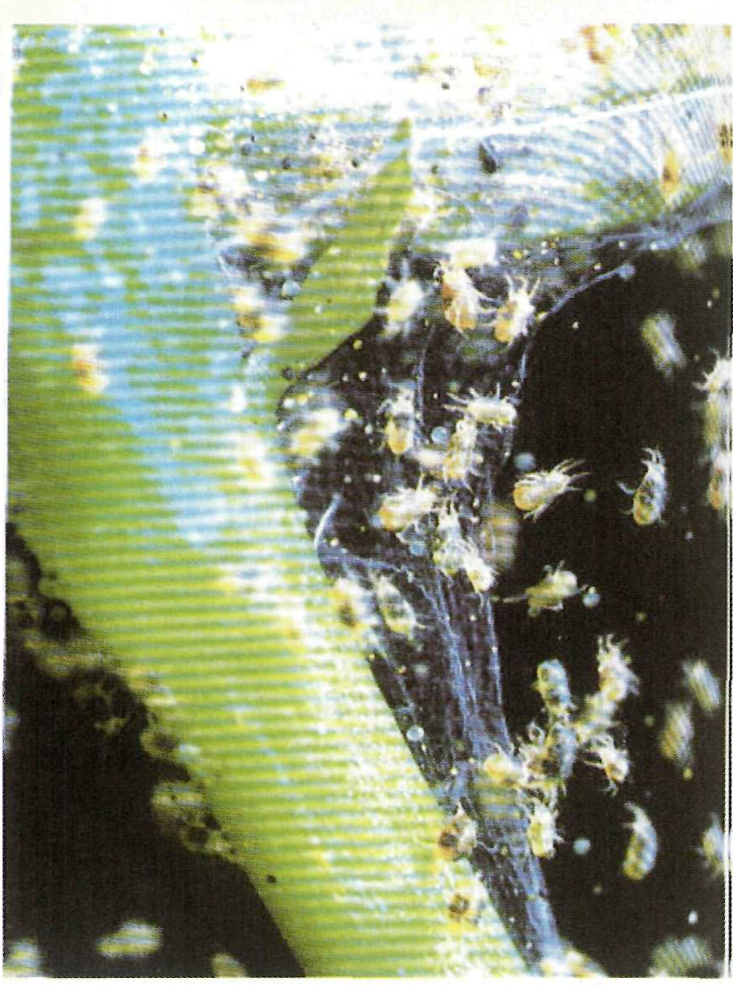
grupos químicos, considerando también el estado biológico en que se encuentra la plaga.

Ferrer y Salvador asegura que: "las circunstancias que hay que tener en cuenta al aplicar las medidas de lucha son:

a) La gran sensibilidad de sus depredadores a los medios de defensa. No se puede realizar los tratamientos indiscriminadamente.

b) Capacidad de crear resistencias a los productos químicos.

c) Gran poder de reproducción.

Como medidas preventivas, considero la sumatoria de los siguientes factores:

1.- Regular la temperatura y humedad relativa del campo. Estas deben ubicarse debajo de los 20 grados centígrados y sobre el $40 \%$ de humedad. Al ácaro le molesta temperaturas bajas y alta humedad, pero esto no le limita su acción y presencia.

2.- Eliminación de hospederos que por lo general se los considera malezas.

3.- Destrucción del material afectado, utilizando podas e incinerándolo.

4.- Mantener la planta vigorosa.

5.- Utilización de predadores como Phytoseiulius persimilis, un ácaro predador contra los ácaros fitófagos como T. urticae. 
La belleza es sensibilidad a lo espiritual...

Medidas químicas:

1.- En la primera fase de ataque actúa bien la aplicación de azufre dirigido al envés de la hoja, sobre todo baja las poblaciones.

2.- Conociendo su ciclo biológico, podemos utilizar:

a) Primera aplicación: para formas móviles ninfas y adultos, productos como Amitráz, Dinobutón, Flufenoxurón, Milbemectín, Abamectina y Pyridaben.

b) Segunda aplicación: ovicidas a los 8 días de la primera aplicación con Hexythiazox, Fenazaquín, Flufenoxurón, Pyridaben y Tebufenpyrad..

c) Tercera aplicación: a los 8 días de la segunda, usar productos enunciados en el

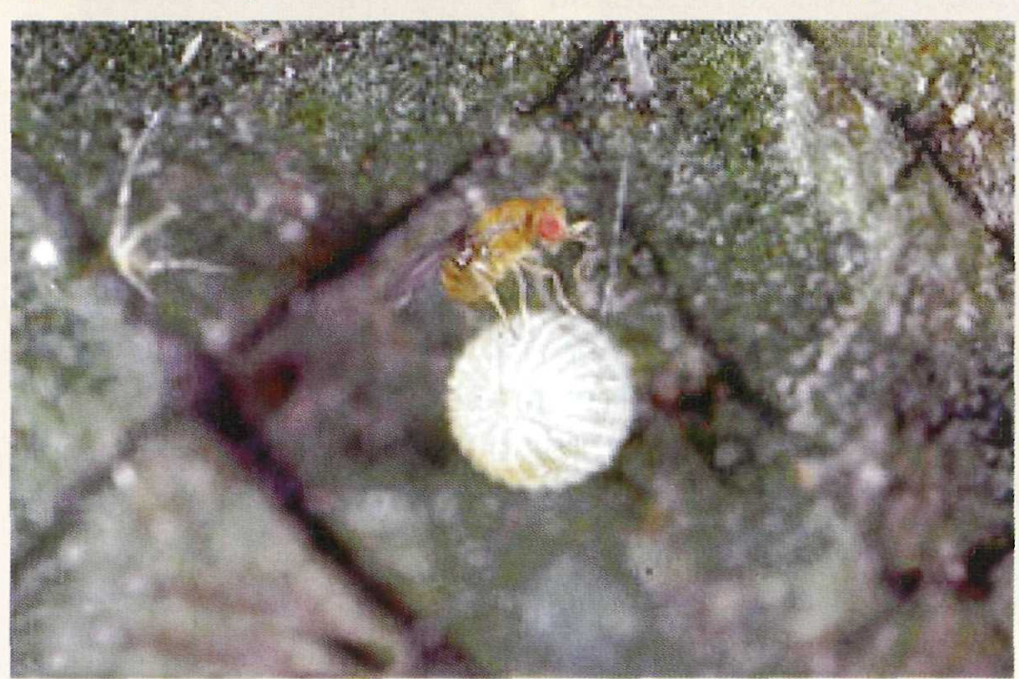
literal a), rotados.

Nota: la sobre dosificación o la disminución de la dosis de un producto no indica que realizará mejor control y economizará dinero según el caso, esto puede acarrear la aceleración del proceso de resistencia del ácaro a la acción del agroquímico. La aplicación del acaricida debe realizarse de forma dirigida, pues la plaga se encuentra en el primer tercio de abajo hacia arriba y el envés de la hoja, siempre que tengamos niveles de población baja.

\section{BIBLIOGRAFÍA}

1.- ARBIAZA AGUINAGA, Alfonso: Guía Práctica y manejo de plagas en 26 cultivos. Impresiones del Castillo. Pág. 10-15. Chiclayo- Perú, 2002.

2.- VADEMECUN AGRICOLA. Pp varias, 2004.

3.-FERRER, Martí y SALVADOR Palomo. La producción de. rosas en cultivo protegido. Editorial Universal Plantas. Págs. 208-211. España, 1986.

* Catedrático de Floricultura, Entomología, Clínica Agrícola 